\title{
Requirements for multicultural competencies defined by a focus group
}

\author{
T. LÁZÁR ${ }^{1}, A ́$. BENE ${ }^{2}$ \\ ${ }^{1}$ University of Debrecen, Faculty of Economics and Business; University of Debrecen Karolylhrig Doctoral School \\ of Management and Business, lazar.timea@econ.unideb.hu \\ ${ }^{2}$ University of Debrecen, Faculty of Health; University of Debrecen KarolyIhrig Doctoral School of Management \\ and Business, beneagi@yahoo.com
}

Abstract Globalization, the spread of multinational companies and the enormous development of information technology can lead to a new trend in employers' requirements. However, being employed by an international company is a real possibility for any employee in any part of the world. Even if they do not have to work abroad, employees may have to function in a multinational environment in their home countries. A favourable combination of intercultural competencies is a key factor in the selection and development of employees. A possible way of measuring these competencies can be the Multicultural Personality Questionnaire (MPQ). First of all,on the employers' part, it is important to clarify the exact requirements and competencies (dimensions) to be able to draw up an 'ideal profile'. We prepared two versions of the MPQ (91-item; 5-dimensional) and used them to test employers' requirements in the selection process regarding the dimensions of cultural empathy, open-mindedness, social initiative, emotional stability and flexibility.

This study describes the results of a focus group interview, which took place in 2017, revealing the importance of multicultural competencies from the employers' point of view and examining the conditions of the adaptability of the two questionnaires. We used the focus group method to find out in what conditions the questionnaires canbe used in a selection process. What possibilities and limits are therefor using the direct five-dimensional questionnaire? What aspects do we need to take into consideration in expressing and interpreting the requirements in the results of the test?

Keywords: multicultural competencies, intercultural requirements, multinational companies, focus group

\section{Introduction}

The concept of globalisation refers to the world full of networks where the different parts of the networks have more connections with each other thus getting closer and closer [9]. The number of multinational companies and the number of people employed by them are increasing all over the world. These multinational companies play a role in Hungary's economy as well.Shared Service Centers (SSCs) have also appeared in Hungary and started to develop at an enormous rate [18]. An important feature of SSCs is that the majority of their employees have a diploma and speak foreign languages. 
According to Poór (2013) by internationalisation, a domestic company expands its activity to foreign markets in a way that its value-added capabilities increase. This means that besides increasing its profit, it can realise other surpluses by enriching its capabilities. An important activity of multinational companies is to spread good practice. They can have a positive effect on social, environmental circumstances, working conditions and on the whole on productivity by their supply chain [13].

Cross-cultural skills have gained increasing importance with the appearance of SSC companies, butthese competencies were highly valued by employers in Hungary. In examining the regional aspect of this, it was found that in requirements towards employees, Human Resources and company managers ranked intercultural skills almost at the same level as professional language competence [10]. When examining the part of those who define the requirements, we can say that besides HR professionals' role, the managers' role and the definition of managers' requirements is a key element of the selection process. Kozák and Móré (2016) emphasise the importance of the managers' role in the integration process at the workplace, which follows the successful selection but is in close relationship with it. Ignoring intercultural differences may lead to difficulties at the workplace in such issues as follows: diverse time management and various meanings of deadlines, differences in the process and length of decision-making, distinct attitudes to the importance of work and differing interpretations of humour [3]. Nonetheless, these competencies can be improved at the workplace, but formal education and foreign language teaching have an important role in improving intercultural competencies. One part of preparing students for the labour market can be the „enriched" language teaching in tertiary education. In selecting teaching materials and methods, higher education teachers need to identify the existing and the newly forming trends in the labour market, as well as anticipate the competency requirements their graduates will have to face upon entering the job market [32].

\section{Intercultural competencies, multicultural competencies}

Working in an international environment means contacting and co-operating with individuals from different cultural backgrounds. The international projects can be intercultural projects at the same time [14].

There are different names with similar meanings in the literature. These are:

- Intercultural communication competence [2];

- Global competence [12];

- Cultural intelligence, in connection withemotional intelligence [21;33];

- Intercultural sensitivity [6;11];

- Multicultural competence, intercultural competence [8;25].

According to Fantini's and Tirmizi's definition (2006) intercultural competence refers to complex capabilities which are needed to be able to communicate effectively and appropriately when we interact with people culturally and linguistically different from us.

In this study, we use intercultural competencies and multicultural competencies as synonyms. Intercultural skills and competencies are present in a new European Union initiative whose aim is to 
help communication across Europe when it comes to working, learning and training between different nations [7]. European Skills, Competencies, Qualifications and Occupations (ESCO) is a multilingual classification system for European qualifications, occupations skills and competencies. ESCO has a common reference terminology to help the labour market. Different skills and competencies are given in connection with interculturalism:

- teach intercultural communication methods,

- apply intercultural teaching strategies,

- demonstrate intercultural competencies in hospitality services,

- demonstrate intercultural competence,

- show intercultural awareness,

- provide security in detention centres,

- foster dialogue in society [34].

Such complex competencies can be defined and measured in different ways. There have been different tests in use for measuring personality traits and skillsregarding multicultural competencies. Some of these tests are the Intercultural Development Inventory, the Test of Intercultural Sensitivity, Intercultural Adjustment Potential Scale; Multicultural Personality Questionnaire. There are also procedures, which use Critical Incidents, as the Culture Assimilator [5].

In this paper, we are going to discuss the Multicultural Personality Questionnaire and the possibilities of applying it in defining employers' requirements in more detail.

\subsection{Multicultural Personality Questionnaire (MPQ), multicultural personality traits}

Multicultural effectiveness means excellent work performance, appropriate adjustment and general psychological well-being and satisfaction in a culturally new environment. It involves successful professional performance, personal adjustment and intercultural interactions [25]

The Multicultural Personality Questionnaire (MPQ) was developed to measure multicultural personality and effectiveness. The questionnaire was used for selecting and training employees working in international scope, and for evaluating employees who have to work with people or groups from different cultural backgrounds. It can be used for defining demands for improvementof the dimensions tested by the questionnaire and for evaluating the success of improvement [29].

The authors of the MPQ summarised a large number of relevant intercultural personality characteristics to five dimensions of intercultural competence [26]. The MPQ consists of 5-point Likert scales for the next dimensions:

1. Cultural empathy

Cultural empathy refers the capacity to identify with the feelings, thoughts, attitude and behaviour of individuals from other cultures [25].

Sample items for this dimension:

"Enjoys getting to know others deeply" [27:51]; 
"Sets others at ease" [27:51].

2. Open-mindedness

Open-mindedness assesses the capacity to be open. Open-minded individuals efficiently acquire the rules and values of a new culture and are keen on the perspectives of different cultural subgroups [24].

Sample items for this dimension:

"Puts his or her own culture in perspective" [27:51];

"Tries out various approaches “[27:51].

3. Social initiative

Social initiative shows a tendency to access social situations actively and to take the initiative [24].

Sample items for this dimension:

"Takes the lead" [27:51];

"Easily approaches other people" [27:51].

4. Emotional stability

Emotional stability denotes the tendency of behaviour in stressful situations [23].

Sample items for this dimension:

"Keeps calm at ill-luck [27:51];

"Takes it for granted that things will turn out right [27:51].

5. Flexibility

Flexibility assesses the ability to adjust behaviour to new and unknown situations and reflects the opposite of rigidity [24].

Sample items for this dimension:

"Works mostly according to a strict scheme" (reversed item) [27:51];

"Starts a new life easily" [27:51].

\section{The Present Study}

The aims of the empirical research described in this paper were the following:

- To identify explanatory fact-finding aspects in the questionnaires for employers' opinions.

- To find out what other important factors can play a role in a selection process in the dimensions of multicultural competencies.

\subsection{The background to the present research}

The background of the present research was empirical research in the forms of questionnaires which took place in the first part of 2017 with the aim of finding out employers' opinions regarding multicultural personality traits of prospective employees.

The steps of the research were the following:

1. Translation of the Multicultural Personality Questionnaire (MPQ, 91 items) into Hungarian (with back-translating).

2. Compilation of a direct five-dimensional version of the questionnaire in Hungarian using the MPQ dimensions.The authors compiled the direct five-dimensional version of the 
questionnaire in Hungarian using the MPQ dimensions. We also made a description of the definitions of the dimensions to provide aclear understanding. The questionnaire without the demographical part can be found in Appendix 1.

3. The collection of data took place in spring, 2017 at three different venues in Debrecen (at Job Expos, $n=12 ; 14 ; 34$; and 5respondents sent the questionnairein email). Data collection took place in a personally assisted way, which opened the door for the respondents' personal reflections that we also noted down.

4. After collecting and cleaning the data, we analysed 31 questionnaires of the 91 -item version and 45 questionnaires of the direct five-dimensional version of the questionnaire (20 respondents filled in both versions). We used $\mathrm{R}$ statistical software for analysing the results according to Abari and Máth (2015).

5. Drawing conclusions and defining further research (expert focus group).

6. Presenting the results at a conference [16].

There have been several studies confirming the advantages of using mixed methods in research. Considering the recommendations of a Hungarian research project [4], we decided to complete our quantitative research with qualitative research methods using a focus group.

Van der Zee and her co-authors wrote in a study in 2013 that they also used focus group methodology in adapting the English version of the MPQ for American- English speakers. [26].We could not find sources in the literature to use focus group methodology in measuring the employers' requirements for multicultural competencies.

\subsection{The methodology of the research}

A focus group (focus group interview can also be used) method belongs to the qualitative research techniques. In general, a focus group is an informal discussion in a group of selected individuals about a determined topic [31]. The interview conducted in a focus group consisting of professionals is an appropriate way to learn several people's opinion at the same time. Its advantage is that it is interactive and flexible [17]. A further advantage is that unlike other types of interviews, the interaction among the participants focuses on a given subject. It is a prevalentrequirement that the participants should be professionally competent experts on the given topic [22]. The significance of the focus group can be that the participants function as a group and can be effectively used in exploratory research. Conducting personal interviews one by one would take much longer, and there is an opportunity to form opinions and exchange experience in the group [19]. Focus groups usually have a predetermined set of questions however the participants also have the possibility for subjective interpretations during the interview. The interviews in focus groups are generally recorded so the answers can be written down later and the moderator does not necessarily have to take notes during the interview [30].

We chose the focus group method because we wanted to learn the professionals' opinion in an exploratory way.

Using a smaller focus group makes it possible to deal with the topic in more depth [30], which has a significance when we would like to bring up all the participants' opinions (even the different ones). 
In addition, we intended to use the focus group to obtain useful additional information from the interaction of the participants. At the same time, we wanted to minimise the unfolding of the group dynamics with the appropriate selection of participants.

The focus group took place on $10^{\text {th }}$ August 2017 with the participation of 5 professionals and a moderator. All the participants gave their agreement to the recording of the interview. In the first part of the focus group the participants filled in both the 91-item questionnaire and the 5-dimensional questionnaire on their own.In the second part of the interview,there was an informal interaction which was conducted by a predetermined set of questions. The interview lasted 2.5 hours.

The preparation of the moderator was very important as she had a complex role. In this focus group, the moderator's role can be characterised by an open, curious attitude. According to her role, she does not have any professional experience in this topic and awaits clarification from the participants. Another part of the previous concept was that with a more active role of the moderator (with the help of the list of the questions) she tried to decrease the unfolding of the group dynamics.

The moderator asked the members of the focus group to fill in the MPQ questionnaires for different reasons:

- Make the participants familiar with the working material;

- Increase the involvement in the topic by personal experience;

- Deepen the professional awareness and attitude in the situation with a professional task;

- Strengthen the team cohesion by task situation.

The aims of filling in the questionnaires did not include the evaluation of the questionnaires and the analysis of the data.

\subsection{The sample}

When selecting the focus groupmembers, we took the following aspects into consideration:

- he/she has managerial experience,

- he/she has experience in working in a multinational environment,

- he/she has taken part recently or is taking part currently in a selection process.

The participants shared their experience with each other and with the moderator (the head of the research) in their free time in exchange for a minimal reward. As they did not have official permission,I disclose their answers and opinions anonymously fulfilling their requests.

Participant „A": a 40-year-oldfemale person with more than 10 years of professional experience in HR, she has been working for a multinational pharmaceutical company as an HR business partner for 2 years in a plant employing about 500 people.

Participant „B”: a 46-year-old female person with more than 10 years of professional experience in HR, she has been working for a multinational IT company as a business operation consultant for 5 years in a plant employing more than 500 people. 
Participant „C": a 35-year-old female person with several years of professional experience, she has been working for a logistics company as an economic fleet operator for 2 years in a plant employing 100-500 people.

Participant „D”: a 27-year-old male person with several years of professional experience, he has been working for a healthcare provider as a compliance manager for 5 years in a plant employing 50-100 people in the private sector.

Participant „E”: a 37-year-old male person with several years of professional experience, he has been working for a multinational energy provider company as a workstream leader for 2 years in a plant employing more than 500 people.

\section{Results}

All the participants agree that multicultural competencies have become more important in the past years (decades) in the Hungarian labour market. This is present in employers' requirements to a greater degree and a lesser degree in students' requirements.

These competencies (cultural empathy, open-mindedness, social initiative, emotional stability and flexibility) are important not only in case of multinational companies but at Hungarian companies as well.

In multicultural competencies, the difference according to gender is not significant, but there is a considerable difference according to generations.

Personal relationship and online relationship with foreigners can improve multicultural competencies thanks to the enormous development of IT technology.

All the respondents say that both questionnaires can be used, but the 91-item is more suitable for experienced HR professionals.Although the results of the 91-item questionnaire can show a more nuanced picture of the respondent, it may be difficult to define the requirements in this version. In addition, it would be advisable to use an ideal profile in the selection process where only the dimensions and not the particular items are present.

It is easier to define the requirements in the 5-dimensional questionnairedirectlybut can be more precise in the 91-item questionnaire. All the requirements defined in the ideal profile should be interpreted for a given position.

They also agree thatall these competencies (cultural empathy, open-mindedness, social initiative, emotional stability and flexibility) play a role only if the applicants meet the professional requirements and in cases when two professionally identical applicants are tested then the direct 5-dimensional questionnaire can be suitable to make the final decision.

It is important to improve these competencies of employees,and as they see it, there is a need for this especially among managers.

They also highlighted that with the internationalisation of universities it would be important to improve the students' multicultural competencies during their studies at university. Study trips, 
student exchange programmes, scholarships, (likeErasmus scholarshipsprograms) and international events organised at universities are beneficial. Meeting people from different cultural backgrounds and formal or informal cooperation isreally useful. The different project work and voluntary teamwork such as organising International Food Day at universities could be good examples.

Appendix 2 contains the statements participants said about the employers' requirements for multicultural competencies.

\section{Summary}

This paper describes the results of a focus group with the use of the two versions of the Multicultural Personality Questionnaire. We used the method of a focus group with an exploratory nature to find out the employers' requirements for multicultural competencies by existing multicultural dimensions in our research. These competencies (cultural empathy, open-mindedness, social initiative, emotional stability and flexibility) are important not only in case of multinational companies but at Hungarian companies as well. On the one hand, because providing a motivating working environment is essential regardless the ownership, as in the labour market there is a harsh competition where employers compete for the same talented young people who would like to work in a dynamic and open environment. On the other hand, the companies which are in Hungarian ownership very often have foreign partners either as suppliers or buyers.

The novelty of the present research is that we used mixed methodology (in the form of questionnaires and focus group) on the topic, applying both quantitative data analysis and qualitative analysis. The focus group methodology was suitable to find out the important factors in using MPQ as a tool of measurement by involving professionals.

The participants of the focus group emphasised that the multicultural competencies in the questionnaires (both the 91-item and the direct 5-dimensional versions of the questionnaire) have played an increasingly important role in employers' requirements in the past years. It is important to improve these competencies of employees as well. In their opinion, there is a need for this, especially among managers. They also highlighted that with the internalisation of universities it would be important to improve the students' multicultural competencies during their studies at university.

The results of the interview show that the direct 5-dimensional MPQ questionnaire has been found to be suitable for defining employers' requirements regarding cultural empathy, open-mindedness, social initiative, emotional stability and flexibility but it has been accepted that the ideal profile must be defined for a given position. This defines the direction of the further research.

Defining an ideal profile for a given position with the help of employers using the direct 5-dimensional MPQ questionnaire will be the next step of the research. 


\section{References}

[1] K. Abari, J. Máth (2015) Tudásterek alkalmazása az oktatásban: Az $R$ statisztikai programcsomag tanítása. In: K. Balázs (ed) Alkalmazott pszichológiai tanulmányok a Szociálés Munkapszichológiai Tanszék fennállásának 25. évfordulójára. Debreceni Egyetemi Kiadó, Debrecen pp. 211-232.

[2] L. A. Arasaratnam, M. L. Doerfel (2005) Intercultural communication competence: Identifying key components from multicultural perspectives. International Journal of Intercultural Relations, 29 (2) pp. 137-163.

[3] T. Bajzát (2010) A mérnökök kommunikatív és interkulturális kompetenciája: elvárások és felkészítés. Doktori értekezés, Pécsi Tudományegyetem.

[4] K. Balázs - Á. Hőgye-Nagy (2015) Kevert módszerű pszichológiai kutatás: A kvalitatív és kvantitatív kutatási módszer integrációja. In: K. Balázs - J. Kovács - Á. Münnich (ed.) Pszichológiai módszertani tanulmányok. Debreceni Egyetemi Kiadó, Debrecen. pp. 9-28.

[5] V. Behrnd - S. Porzelt (2012) Intercultural competence and training outcomes of students with experiences abroad. International Journal of Intercultural Relations, 36 (2) pp. 213-223.

[6] G. M. Chen - W. J. Starosta (2000) The development and validation of the intercultural sensitivity scale. Communication Studies Faculty Publications, The University of Rhode Island, Human Communication 3 (1) pp. 1-15.

[7] EUROPEAN COMMISSION (2017) ESCO Strategic framework European Skills, Competences, Qualifications and Occupations, letöltés: 2018. 03. 04., web: https://ec.europa.eu/esco/portal/document/en/01192a20-a7c0-4d0d-b5d3-29d1f9b819c8

[8] A. Fantini, A. Tirmizi (2006), Exploring and Assessing Intercultural Competence, World Learning Publications, letöltés: 2018. március 17.2 web: http://digitalcollections.sit.edu/worldlearning_publications/1

[9] J. Gács (2007) A gazdasági globalizáció számokban A nyitottság alakulása az EU országaiban-I. rész. Közgazdasági Szemle 54 (10) pp. 876-902.

[10] Z. Hajdu (2008) Kompetencia elvárások vizsgálata, különös tekintettel az idegennyelv-tudásra, az Észak-alföldi régióban, Doktori értekezés. Debreceni Egyetem.

[11] M. R. Hammer - J. B. Milton - R. Wiseman (2003) Measuring intercultural sensitivity: The intercultural development inventory. International journal of intercultural relations 27 (4) pp. 421-443.

[12] B. Hunter - G. P. White - G. C. Godbey (2006) What does it mean to be globally competent? Journal of Studies in International Education 10 (3) pp. 267-285.

[13] A. Kazainé Ónodi (2012) Fenntartható fejlődés a nemzetközivé válás folyamatában. Mủhelytanulmány, Vállalatgazdaságtan Intézet, Budapest.

[14] D. J. Kealey - D. R. Protheroe - D. MacDonald - T. Vulpe (2006), International projects: some lessons on avoiding failure and maximizing success. Performance Improvement 45 (3) pp. 3846.

[15] A. Kozák - M. Móré (2016) A munkahelyi beillesztés csoportintegrációs tényezői, Tudásmenedzsment 17 (2) pp. 110-117.

[16] T. Lázár - Á. Bene (2017) Multikulturális kompetenciák iránti igény nemzetközi hátterú vállalatok toborzásában" In: K. Dajnoki - Cs. Berde (ed.) A globalizáció és a változás hatása az emberi erőforrás menedzsment funkciókra. Rezümékötet. DE GTK, Debrecen. p. 40. 
[17] P. Majoros (2004) A kutatásmódszertan alapjai. Perfekt.

[18] R. Marciniák (2014) Osztott szolgáltatások-egy innovatív forma vizsgálata. Doktori értekezés, Miskolci Egyetem.

[19] D. Molnár (2010), Empirikus kutatási módszerek a szervezetfejlesztésben. Humán Innovációs Szemle 1 (1-2) pp. 61-72.

[20] J. Poór (2013) Nemzetköziesedés az emberi erőforrás menedzsmentben, Doktori értekezés, Szent István Egyetem

[21] J. R. Ramsey - R. M. Rutti - M. P. Lorenz - L. L. Barakat - A. S. Sant'anna (2017) Developing global transformational leaders. Journal of World Business 52 (4) pp. 461-473.

[22] M. Saunders - P. Lewis - A. Thornhill (2007) Business research methods. Fourth edition, Financial Times, Prentice Hall: London.

[23] K. van Der Zee - J. P. van Oudenhoven - E. de Grijs (2004) Personality, threat, and cognitive and emotional reactions to stressful intercultural situations. Journal of personality 72 (5) pp. 10691096.

[24] K. van Der Zee - N. Atsma - F. Brodbeck (2004) The influence of social identity and personality on outcomes of cultural diversity in teams. Journal of cross-cultural psychology 35 (3) pp. 283303.

[25] K. van Der Zee - J. P. van Oudenhoven (2000) The Multicultural Personality Questionnaire: A multidimensional instrument of multicultural effectiveness. European Journal of Personality 14 (4) pp. 291-309.

[26] K. van der Zee - J. P. van Oudenhoven - J. G. Ponterotto - A. W. Fietzer (2013) Multicultural Personality Questionnaire: Development of a Short Form. Journal of Personality Assessment 95 (1) pp. $118-124$

[27] J. P. van Oudenhoven - V. Benet-Martínez (2015) In search of a cultural home: From acculturation to frame-switching and intercultural competencies. International Journal of Intercultural Relations 46 pp. 47-54.

[28] J. P. van Oudenhoven - K. I. Van der Zee (2002) Predicting multicultural effectiveness of international students: The Multicultural Personality Questionnaire. International Journal of Intercultural Relations 26 (6) pp. 679-694.

[29] J. P. van Oudenhoven - M. E. Timmerman - K. van Der Zee (2007) Cross-cultural equivalence and validity of the Multicultural Personality Questionnaire in an intercultural context. Journal of International Communication 13 (2) pp. 51-65.

[30] L. Vicsek (2006) Fókuszcsoport, Osiris.

[31] S. Wilkinson (2004) Focus groups: A feminist method. In S.N. Hesse-Biber, M.L. Yaiser (eds.), Feminist perspectives on social research. Oxford University Press, New York. pp. 271-295.

[32] T. B. Wiwczaroski - M. Czellér (2017) Meeting needs: Foreign language instruction in higher education and the job market. In: R. Štefančík, R. Kapil (eds.) Cudzie jazyky v premenách času VII. / Foreign Languages in Changing Times VII. Recenzovanỳ zborník prívspevkov z mezdinárodnej vedeckej konferencie / Reviewed Conference Proceedings from an International Scientific Conference. 223 p.

[33] S. H. Yoo - D. Matsumoto - J. A. LeRoux (2006) The influence of emotion recognition and emotion regulation on intercultural adjustment. International Journal of Intercultural Relations 30 (3) pp.345-363.

[34] Internet 1. https://ec.europa.eu/esco/portal/skill 


\section{Appendix}

\section{Appendix 1.}

The 5-dimensional direct MPQ Questionnaire (without the demographical part of the questionnaire)

We would like to know that in your opinion what is the 'ideal' employee like who would be suitable in the dimensions regarding the multicultural personality at your company, supposing the adequacy of the professional competencies or any other personal competencies outside the scope of this questionnaire.

We gave precise descriptions of the endpoints of the dimensions.

Please indicate the appropriate number according to you for the 'ideal' employee. You can also indicate values in between.

\section{Example: Loyalty}

How loyal is he/she towards the company?

$\begin{array}{llllllll} & 1 & 2 & 3 & 4 & 5 & \\ \text { slightly } & & & & & & \text { extremely }\end{array}$

Please fill in the 'MPQ- Multicultural Personality Questionnaire' dimensional profiles for the 'ideal' employee.

The 'ideal' employee's profile

1. Cultural empathy

How can he/she identify with the feelings, thoughts and behaviour of individuals from another culture?

$\begin{array}{llllll} & 1 & 2 & 3 & 4 & 5 \\ \text { with difficulty } & & & & & \text { easily }\end{array}$

2. Open-mindedness

How open is he/she with individuals from another culture?

$\begin{array}{llllll}\text { closed } & 1 & 2 & 3 & 4 & 5 \\ & & & & \text { absolutely open }\end{array}$

\section{Social initiative}

How does he/she interact with people from different cultures?

$\begin{array}{llllll} & 1 & 2 & 3 & 4 & 5 \\ \text { with difficulty } & & & & & \text { easily }\end{array}$

\section{Emotional stability}

How calm can he/she stay in stressful situations?

$$
\text { not at all totally }
$$

\section{Flexibility}

How can he/she adjust to unknown situations?

$\begin{array}{lllcc}1 & 2 & 3 & 4 & 5\end{array}$




\section{Thank you for filling in the questionnaire.}

\section{Appendix 2.}

A table containing the statements the participants of the focus group said about the employers' requirements for multicultural competencies

\begin{tabular}{|c|c|c|c|c|c|}
\hline Statements & „A" & „B” & „C" & „D” & „E” \\
\hline $\begin{array}{l}\text { The profile should be prepared for a given position. The following should } \\
\text { be considered: teamwork } \% \text {, foreign team member: yes/no, foreign } \\
\text { assignment: yes/no, connection with foreign partners: yes/no }\end{array}$ & $*$ & $*$ & $*$ & $*$ & $*$ \\
\hline $\begin{array}{l}\text { Drawing up an ideal profile should be teamwork (HR professionals and } \\
\text { area managers) }\end{array}$ & $*$ & $*$ & $*$ & $*$ & $*$ \\
\hline The applicant's professional aptitude is the most important. & $*$ & $*$ & $*$ & $*$ & $*$ \\
\hline These competencies can be improved at the university. & $*$ & $*$ & $*$ & $*$ & $*$ \\
\hline $\begin{array}{l}\text { Foreign exchange programmes, scholarships are useful. (at the company } \\
\text { and university) }\end{array}$ & $*$ & $*$ & $*$ & $*$ & $*$ \\
\hline In the given competencies there is no difference according to gender. & * & $*$ & $*$ & $*$ & $*$ \\
\hline $\begin{array}{l}\text { In special areas, there can be differences according to gender deriving } \\
\text { from specialisations. }\end{array}$ & & $*$ & $*$ & $*$ & \\
\hline In the given competencies there are differences according to generations. & $*$ & $*$ & $*$ & $*$ & $*$ \\
\hline There are differences in improving these skills according to generations. & $*$ & $*$ & $*$ & $*$ & * \\
\hline The competencies of the person conducting the selection are important. & $*$ & $*$ & $*$ & $*$ & $*$ \\
\hline $\begin{array}{l}\text { These competencies can be improved in the workplace (training, } \\
\text { mentoring) }\end{array}$ & $*$ & $*$ & $*$ & $*$ & $*$ \\
\hline Managers should be improved in these areas. & $*$ & $*$ & $*$ & $*$ & $*$ \\
\hline $\begin{array}{l}\text { Having a personal relationship with somebody from a different culture is } \\
\text { an advantage. }\end{array}$ & $*$ & $*$ & $*$ & $*$ & $*$ \\
\hline Foreign work experience is an advantage. & * & $*$ & $*$ & $*$ & $*$ \\
\hline Language knowledge is essential. & $*$ & $*$ & $*$ & $*$ & $*$ \\
\hline The methodology of language teaching is essential. & $*$ & $*$ & $*$ & $*$ & $*$ \\
\hline Informal relationships with people from different cultures are useful. & $*$ & $*$ & $*$ & $*$ & $*$ \\
\hline $\begin{array}{l}\text { The job interview conducted in a foreign language is a good way to test } \\
\text { multicultural competencies. }\end{array}$ & $*$ & & & $*$ & $*$ \\
\hline $\begin{array}{l}\text { The role of the corporate culture. The corporate culture and the customs of } \\
\text { the parent company and the subsidiary. }\end{array}$ & $*$ & $*$ & $*$ & $*$ & $*$ \\
\hline $\begin{array}{l}\text { The parameters of the team where we are looking an employee are } \\
\text { important. }\end{array}$ & $*$ & $*$ & * & $*$ & $*$ \\
\hline The role of good practices.(For example spouse training) & $*$ & $*$ & $*$ & $*$ & $*$ \\
\hline
\end{tabular}


International Journal of Engineering and Management Sciences (IJEMS) Vol. 3. (2018). No. 3

DOI: 10.21791/IJEMS.2018.3.4.

If the applicant is too open his/her loyalty is questionable. 